\title{
PENINGKATAN PENGETAHUAN PENGASUH LANSIA TERKAIT PERAN LATIHAN FISIK DALAM MANAJEMEN TERPADU OSTEOARTHRITIS
}

\author{
Rea Ariyanti ${ }^{1)}$, Cecilia Widijati Imam ${ }^{1)}$ \\ ${ }^{1)}$ Sarjana Terapan Manajemen Informasi Kesehatan, STIKes Panti Waluya Malang, Malang, \\ Jawa Timur, Indonesia \\ Corresponding author : Rea Ariyanti \\ E-mail : ariantirea@gmail.com
}

Diterima 10 September 2021, Direvisi 17 Sepetember 2021, Disetujui 17 September 2021

\begin{abstract}
ABSTRAK
Adanya kebijakan dari pemerintah terkait pandemi covid 19 turut memberikan dampak bagi masyarakat, salah satunya dari aspek kesehatan seperti terhambatnya akses untuk mendapatkan layanan fasilitas kesehatan, terutama pada lansia. Salah satu penyakit yang paling sering terjadi pada lansia adalah osteoarthritis. Osteoarthritis merupakan penyakit rematik akibat gangguan metabolisme yang diikuti oleh beberapa perubahan pada sistem muskuloskeletal pada lansia. Dengan diberikannya pelatihan pada pengasuh lansia terkait peran latihan fisik dalam manajemen terpadu osteoarthritis diharapkan pengasuh lansia dapat membantu lansia dalam upaya pencegahan secara mandiri penyakit osteoartritis. Program kemitraan ini bertujuan untuk meningkatkan pemahaman pengasuh lansia terhadap peran latihan fisik dalam manajemen terpadu osteoarthritis. Kegiatan ini dilaksanakan di Panti Werdha Tresno Muti Turen Kabupaten Malang, sebanyak 3 kali melalui pemberian materi dan video pembelajaran, serta melaksanakan diskusi interaktif kepada 25 orang pengasuh lansia. Dari hasil evaluasi yang dilakukan, diketahui bahwa terjadi peningkatan pemahaman para pengasuh lansia, dimana sebelum diberikan penyuluhan, rata-rata nilai pre test sebesar 60,00 dan setelah diberikan penyuluhan terjadi peningkatan nilai post test menjadi 84,00 . Kegiatan ini perlu dilakukan sebagai upaya meningkatkan kesadaran, kepedulian dan mendorong keterlibatan peran pengasuh lansia dan para lansia dalam upaya manajemen terpadu pencegahan osteoarthritis melalui latihan fisik.
\end{abstract}

Kata kunci: lansia; latihan fisik; manajemen terpadu; osteoarthritis

\begin{abstract}
The existence of policies from the government related to the COVID-19 pandemic also has an impact on the community, one of which is from the health aspect such as hampering access to health facilities, especially for the elderly. One of the most common diseases in the elderly is osteoarthritis. Osteoarthritis is a rheumatic disease due to metabolic disorders followed by several changes in the musculoskeletal system in the elderly. By providing training to elderly caregivers regarding the role of physical exercise in the integrated management of osteoarthritis, it is hoped that elderly caregivers can help the elderly in efforts to independently prevent osteoarthritis. This partnership program aims to increase the understanding of elderly caregivers on the role of physical exercise in the integrated management of osteoarthritis. This activity was carried out at the Tresno Muti Turen Nursing Home, Malang Regency, 3 times through the provision of learning materials and videos, as well as carrying out interactive discussions with 25 elderly caregivers. From the results of the evaluation, it was found that there was an increase in the understanding of the elderly caregivers, where before being given counseling, the average pre-test score was 60.00 and after being given counseling there was an increase in the posttest score to 84.00. This activity needs to be carried out as an effort to increase awareness, concern and encourage the involvement of the role of elderly caregivers and the elderly in an integrated management effort to prevent osteoarthritis through physical exercise.
\end{abstract}

Keywords: elderly; integrated management; osteoarthritis; physical training

\section{PENDAHULUAN}

Pandemi COVID-19 yang sedang melanda Indonesia turut memberikan dampak bagi suatu desa di berbagai daerah. Covid 19 bukan hanya merupakan suatu wabah biasa, melainkan suatu pandemi. WHO (World Health
Organization) sebagai organisasi kesehatan dunia mengemukakan untuk menghentikan penyebaran pandemi covid 19 harus ada titik dimana kita bisa melakukan lockdown atau tidak, akan tetapi hal ini masih bersifat debatable, yaitu menimbulkan pro dan kontra. 
Melihat angka-angka yang kian hari terus mengalami peningkatan, tentu akan menimbulkan kecemasan dan kekhawatiran, khususnya bagi masyarakat Indonesia. Adanya kebijakan dari pemerintah juga turut memberikan dampak bagi masyarakat, bukan hanya dari aspek ekonomi, melainkan juga dari aspek kesehatan. Salah satu dampak yang cukup dirasakan oleh masyarakat dengan adanya pandemi covid 19 ini adalah terhambatnya akses warga untuk mendapatkan layanan fasilitas kesehatan.

Lansia atau lanjut usia adalah seseorang yang mencapat usia 60 tahun keatas (Kementerian Kesehatan RI, 2019). Proses menua merupakan proses dimana terjadinya penurunan fungsi organ dan penurunan perkembangan fisik yang tidak dapat dihindari. Jumlah lansia dari tahun ke tahun terus bertambah seiring dengan meningkatnya jumlah harapan hidup. Proporsi lanjut usia di dunia menunjukkan peningkatan setiap tahunnya. Saat ini jumlah penduduk lansia di dunia diperkirakan mencapai 500 juta dan pada tahun 2025 diprediksi akan mencapai 1,2 miliar. Sementara itu peningkatan jumlah lansia juga terjadi di Asia dari 2,3\% menjdai 7,8\% (Meiner, 2011). Menteri Kesehatan pada tahun 2014, mencatat jumlah lansia di Indonesia berjumlah 18.781 juta jiwa dan pada tahun 2015 jumlahnya akan mencapai 36 juta jiwa. Indonesia merupakan negara ke-4 terbesar di dunia yang memiliki jumlah usia lanjut setelah China dan India. Data dari Survei Sosial Ekonomi Nasional tahun 2016 menunjukkan bahwa jumlah lansia di Indonesa mencapai 22,4 juta jiwa atau 8,69\% dari jumlah penduduk (Kementerian Kesehatan RI, 2014).

Osteoarthritis (OA) adalah penyakit rematik yang paling sering mengenai lansia akibat gangguan metabolisme yang diikuti oleh beberapa perubahan pada sistem muskuloskeletal pada lansia. OA merupakan penyakit degeneratif pada persendian yang melibatkan kartilago, lapisan sendi, ligamen, dan tulang sehingga dapat menyebabkan nyeri dan kekakuan pada sendi (Center for Disease Control and Prevention, 2014). Penyakit OA hampir $70 \%$ dialami oleh mereka yang berusia diatas 50 tahun ditandai dengan adanya kerusakan struktur dalam persendian. Penyakit ini sebagian besar berlokasi di tangan, pergelangan tangan, serta sendi-sendi yang menahan beban tubuh seperti lutut, pinggul, dan punggung dikarenakan proses penekanan yang terus menerus selama bertahun-tahun (Kemenkes P2PTM, 2016).

OA sampai dengan saat ini masih merupakan masalah kesehatan utama di dunia. World Health Organization (WHO) menyatakan bahwa OA merupakan salah satu penyebab utama kegagalan fungsi yang mengurangi kualitas hidup manusia di dunia seperti terhambatnya ruang gerak penderita, terjadi penurunan kemampuan kerja, mampu menyebabkan nyeri hebat dan cacat pada penderita, sehingga dapat mengganggu aktivitas sehari-hari. Akibatnya, sebanyak $80 \%$ penderita akan mengalami keterbatasan dalam bergerak dan, sisanya bahkan tidak dapat melakukan kegiatan sehari-hari (WHO, 2016). Prevalensi OA di Asia diperkirakan akan meningkat sebanyak dua kali lipat dari $6,8 \%$ pada tahun 2008 , menjadi $16,2 \%$ pada tahun 2040. Kementerian Kesehatan RI (2012), memetakan jumlah penderita OA, hasilnya sekitar lebih dari $11,5 \%$ orang Indonesia menderita OA. Artinya pada setiap 10 penduduk Indonesia terdapat 1 orang penderita OA (Prieharti dan Mumpuni, 2017). Di Indonesia, angka OA masih cukup tinggi yaitu mencapai 36,5 juta orang, dimana prevalensi terbesar terjadi pada usia lebih dari 75 tahun yaitu sebesar $58,8 \%$, diikuti usia $65-74$ tahun sebesar 51,9\%, usia 55-64 tahun sebesar $45,0 \%$, dan usia $45-54$ tahun sebesar $37,2 \%$. Sedangkan berdasarkan data dari RISKESDAS (2013) dijetahui bahwa angka kejadian OA di Indonesia banyak terjadi pada perempuan yaitu $27,5 \%$ dan laki-laki yaitu 21,8\% (Kemenkes RI, 2014). Penyebab pasti dari penyakit OA ini belum bisa dipastikan, namun beberapa faktor risiko seperti penuaan dan berat badan berlebih merupakan dua faktor yang dominan (Rahmawati dan Sirojuddin, 2012). Penyakit OA ini bersifat multifaktorial yang disebabkan oleh berbagai faktor risiko seperti lanjut usia, obesitas, trauma pada sendi, kelainan genetik pada tulang rawan sendi dan tekanan berlebih pada sendi yang disebabkan oleh olahraga (Tika dan Aryana, 2018). Gejala utama yang paling umum dirasakan penderita $O A$ adalah nyeri dan kekakuan pada sendi. Nyeri sendi dapat terjadi ketika aktifitas terlalu berlebihan. Kekakuan pada sendi dikarenakan tidak adanya pergerakan atau aktifitas pada presendian, umumnya timbul di pagi hari ketika baru bangun tidur atau setelah beristirahat di siang hari. Sendi juga dapat mengalami kemerahan, hangat disertai dengan nyeri tekan kemudian terdapat rasa kaku, imobilitas dan deformitas. Apabila terjainya pembentukan osteofit pada sendi tangan atau sendi kaki bisa menyebbakan pembengkakan atau deformitas sendi yang dapat membatasi ruang gerak penderita, dapat mengganggu dan mempengaruhi pada kesejahteraan fisik. Selain itu, OA dapat memiliki dampak mendalam pada setiap aspek kehidupan seseorang dan dapat menyebabkan kecacatan jika tidak diobati 
dengan benar (Ignatavicius dan Workman, 2015).

Panti werda Usia "Tresno Mukti" adalah
salah satu cabang Pelayanan Bala Keselamatan di Indonesia. Secara Organisasi berada di bawah Sekretaris Sosial Kantor Pusat Teritorial yang berkedudukan di Bandung. Seiring dengan kemajuan teknologi dibidang kesehatan yang berdampak pada semakin banyaknya usia lanjut, maka Bala keselamatan merasa perlu memberikan perhatian besar untuk pelayanan kepada para lanjut usia. Jumlah lansia yang saat ini ada di Panti Werda Usia Tresno Mukti adalah 24 orang. Berdasarkan hasil pengkajian awal dengan pengelola panti werdha usia Tresno Mukti, diketahui bahwa mayoritas lansia yang ada di Panti Werda Usia Tresno Mukti sering mengeluhkan rasa sakit dibagian sendi. Ditambah dengan kondisi pandemi yang sedang terjadi saat ini, dampak yang cukup dirasakan juga adalah terhambatnya akses untuk mendapatkan layanan fasilitas kesehatan, sehingga para pengelola dan pengasuh lansia di Panti Werdha Usia Tresno Mukti mengalami kesulitan untuk mengatasi rasa nyeri pada bagian sendi yang dirasakan oleh para lansia.

Berdasarkan penelitian yang dilakukan oleh Marlina pada tahun 2015, menyatakan bahwa melakukan latihan fisik secara teratur memiliki pengaruh yang signifikan terhadap kejadian OA. Hal ini disebabkan karena latihan fisik yang dilakukan secara teratur dapat meningkatkan peredaran darah sehingga metabolisme meningkat dan terjadi peningkatan difusi cairan sendi melalui matriks tulang. Pemenuhan kebutuhan nutrisi tulang rawan sangat tergantung pada kondisi cairan sendi, jadi jika cairan sendi baik maka suplai nutrisi untuk tulang rawan menjadi adekuat. Selain itu, adanya kontraksi otot quadriceps dan hamstring yang kuat akibat latihan fisik maka akan mempermudah mekanisme pumping action sehingga proses metabolisme dan sirkulasi lokal dapat berlangsung dengan baik (Marlina, 2015).

Imobilitas sering dialami orang dengan OA, biasanya karena nyeri, maka selanjutnya dapat mengakibatkan disabilitas. Berkurang nya mobilitas dapat meningkatkan risiko bertambahnya berat badan, yang dapat memperberat beban pada sendi yang terkena OA. Selanjutnya orang dengan OA akan semakin tergantung pada orang lain dan mengakibatnya semakin menurunkanya kualitas hidup. Semakin jarang sendi digunakan, makin lemah, dan kaku, sehingga mengakibatkan pasien semakin sulit untuk meningkatkan aktivitas. Guna menghindari hal tersebut, maka dapat diberikan edukasi terkait upaya pencegahan yang dapat dilakukan secara mandiri dan memberikan program latihan yang baik, dilakukan seawal mungkin pada kondisi pasien yang memungkinkan, salah satunya dengan memberikan edukasi terkait latihan fisik yang dapat dilakukan sebagai upaya dalam mencegah terjadinya OA.

Berdasarkan latar belakang tersebut, maka tim pengabdi tertarik untuk melaksanakan kegiatan PkM dengan judul "Pelatihan Kesehatan pada Pengasuh Lansia terkait Peran Latihan Fisik dalam Manajemen Terpadu Osteoarhritis di Tengah Pandemi Covid 19 di Panti Tresno Mukti Turen Kabupaten Malang. Program kemitraan ini bertujuan untuk meningkatkan pemahaman pengasuh lansia terhadap peran latihan fisik dalam manajemen terpadu osteoarthritis.

\section{METODE}

Metode yang digunakan untuk mencapai tujuan dari program kemitraan ini adalah dengan memberikan penyuluhan tentang osteoartritis pada lansia dan peran latihan fisik dalam manajemen terpadu penyakit ostaoertirits, memberikan video pembelajaran, dan dilanjutkan dengan diskusi interaktif.

Kegiatan Kemitraan dilaksanakan di Panti Werda Usia "Tresno Mukti" Turen Kabupaten Malang. Panti werda Usia "Tresno Mukti" adalah salah satu cabang Pelayanan Bala Keselamatan di Indonesia. Jumlah lansia yang saat ini ada di Panti Werda Usia Tresno Mukti adalah 24 orang. Sedangkan jumlah pengasuh lansia yang ada di Panti Werda Usia "Tresno Mukti" sejumlah 25 orang.

Sebelum melaksanakan kegiatan, tim pengabdi bersama-sama menetukan prioritas masalah yang terjadi pada lansia. Kegiatan penyuluhan dilaksanakan sebanyak 3 (tiga) kali yaitu pada tanggal 01 Juli dengan materi osteoarthritis, tanggal 15 Juli dengan materi upaya pencegahan osteoarthritis dan 05 Agustus 2021 dengan materi peran latihan fisik dalam manajemen terpadu osteoarthritis. Kegiatan dilaksanakan dengan metode ceramah dan diskusi interaktif bersama 25 orang pengasuh lansia. Kegiatan Penyuluhan disampaikan oleh 2 pemateri yaitu Dosen dari Program Studi D-IV Manajemen Informasi Kesehatan.

Monitoring dan evaluasi dilakukan melalui lembar kuesioner berupa pretes dan postest. Untuk menilai tingkat pemahaman pengasuh lansia terkait penyakit osteoarthritis khususnya peran latihan fisik dalam manajemen terpadu osteoarthritis, maka sebelum diberikan penyuluhan, para kader akan dilakukan pretest dan di akhir penyuluhan 
akan dilakukan posttest. Secara garis besar, pertanyaan yang dicantumkan pada pre dan posttest adalah pertanyaan seputar osteoarthritis seperti definisi osteoarthritis, faktor risiko osteoartritis, penyebab osteoarthritis, dampak osteoarthritis, serta peran latihan fisik dalam manajemen terapdu penyakit osteoarthritis.

\section{HASIL DAN PEMBAHASAN}

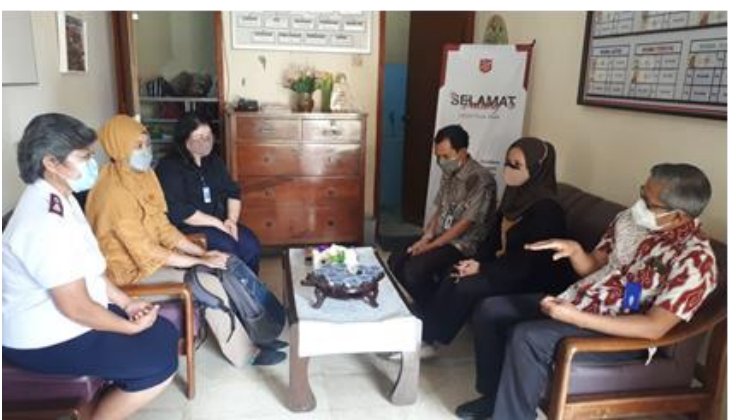

Gambar 1. Koordinasi dengan mitra

Berdasarkan hasil pengkajian awal dengan pengelola panti werdha usia Tresno Mukti, diketahui bahwa mayoritas lansia yang ada di Panti Werda Usia Tresno Mukti sering mengeluhkan rasa sakit dibagian sendi. Ditambah dengan kondisi pandemi yang sedang terjadi saat ini, dampak yang cukup dirasakan juga adalah terhambatnya akses untuk mendapatkan layanan fasilitas kesehatan, sehingga para pengelola dan pengasuh lansia di Panti Werdha Usia Tresno Mukti mengalami kesulitan untuk mengatasi rasa nyeri pada bagian sendi yang dirasakan oleh para lansia. Berdasarkan hasl tersebut, maka tim pengabdi bersama-sama dengan tim pengelola membuat prioritas masalah (Gambar 1), dan menentukan pelaksanaan kegiatan. Dari hasil diskusi, maka disepakati bahwa kegiatan PkM akan dilaksanakan sebanyak 3 kali dengan materi pengenala osteoarthritis, pencegahan osteoarhtritis, dan peran latihan fisik dalam upaya manajemen terpadu penyakit osteaorthritis pada lansia.

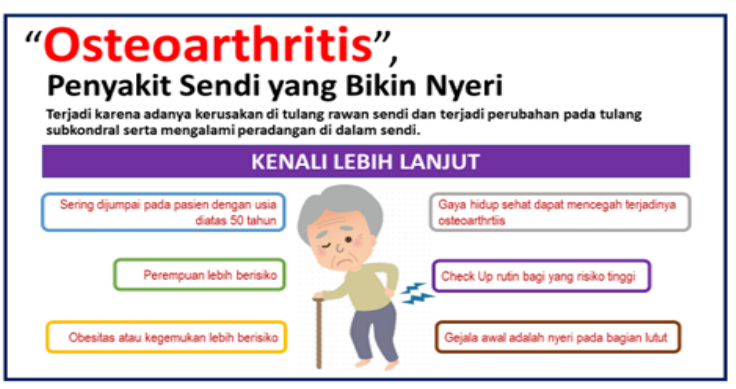

Gambar 2. Materi Hari ke 1

Pelaksanaan PkM hari 1 dilaksanakan pada tanggal 1 Juli 2021. Sebelum memberikan materi, tim pengabdi memberikan kuesioner melalui google form kepada pengasuh lansia, selanjutnya memberikan penyuluhan kepada pengasuh lansia terkait osteoarthritis pada lansia (Gambar 2). Pada kesempatan ini, Fasilitator menyampaikan materi tentang osteoarthritis pada lansia dengan metode penyuluhan, kemudian dilanjutkan dengan memberikan kesempatan kepada responden untuk mengajukan pertanyaan.

Pelaksanaan PkM hari 2 dilaksanakan pada tanggal 15 Juli 2021 dengan memberikan penyuluhan kepada pengasuh lansia terkait upaya pencegahan osteoarthritis pada lansia. Pada kesempatan ini, Fasilitator Memberikan penyuluhan kepada kader terkait Upaya Pencegahan Penyakit Osteoarthritis Pada Lansia

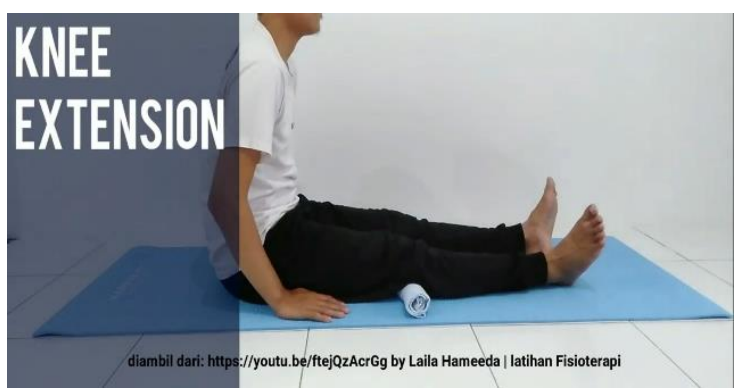

Gambar 3. Pemberian Materi Hari ke 3

Pelaksanaan PkM hari 3 dilaksanakan pada tanggal 5 Agustus 2021 dengan memberikan penyuluhan kepada pengasuh lansia terkait osteoarthritis pada lansia. Pada kesempatan ini, Fasilitator menyampaikan materi tentang Peran Latihan Fisik dalam Manajemen Terpadu Osteoarthritis Pada Lansia dengan metode pemberian video pembelajaran (Gambar 3), kemudian dilanjutkan dengan memberikan kesempatan kepada kader untuk mengajukan pertanyaan, dan diakhiri dengan memberika kuesioner melalui google form untuk menilai pemahaman para pengasuh lansia.

\section{HASIL PRE \& POST TEST}

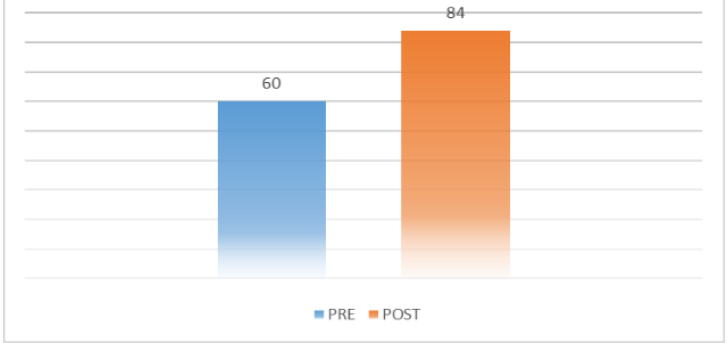

Gambar 4. Hasil Pre dan Post

Dari hasil evaluasi proses kegiatan, diketahui bahwa pengasuh lansia sangat antusias dalam kegiatan, yang ditandai dengan para pengasuh lansia aktif untuk berdiskusi 
terkait materi yang diberikan. Selain itu, Evaluasi tingkat pemahaman pengasuh lansia terkait materi juga telah diberikan, dengan memberikan kuesioner melalui google form. Kuesioner diberikan pada saat sebelum dan setelah diberikan penyuluhan. Dari hasil evaluasi, diketahui bahwa terjadi peningkatan pemahaman pengasuh lansia. Hal ini ditandai diketahui dengan membandingkan nilai pre test dan post test. hasil evaluasi nilai pre dan post test kegiatan PkM). Rata-Rata Nilai Pre Test sebesar 60.00 dan Nilai Post Test sebesar 84,00 .

Pelaksaan Program Kemitraan ini, tim pengabdi sempat mengalami beberapa kendala. Pada awalnya, Pelaksanaan PkM disepakati akan dilaksanakan secara luring, akan tetapi dikarenakan kondisi Pandemi yang saat itu mengalami peningkatan yang cukup drastis, maka tim pengabdi dan pengelola dari Panti Werda Usia "Tresno Mukti" Turen Kabupaten Malang memutuskan untuk kegiatan dilaksanakan secara daring untuk meminimalkan risiko.

Perilaku kesehatan merupakan segala aktivitas atau kegiatan seseorang, baik yang dapat diamati secara langsung maupun yang tidak dapat diamati yang berkaitan dengan pemeliharaan atau peningkatan kesehatan. Berdasarkan teori dasar yang dikembangkan oleh Lawrence Green (1991) dalam Nursalam (2014:80), perilaku kesehatan seseorang dipengaruhi oleh dua hal pokok yang utama, salah satunya adalah tingkat pengetahuan. Sebagian besar pengetahuan manusia diperoleh melalui mata dan telinga seperti poster, majalah, atau sumber informasi yang berbentuk tulisan dan informasi yang berbentuk suara seperti seminar, penyuluhan, atau pembicaraan dari orang lain melalui percakapan sehari-hari. Penyuluhan yang dilakukan dengan metode yang tepat dapat menarik perhatian serta mempermudah pemahaman terhadap penyuluhan yang diberikan. Dengan diberikannya penyuluhan, maka responden yang semula belum mengetahui menjadi mengetahui dan memahami, sehingga diharapkan dapat meningkatkan perilaku kesehatannya (Muthia dalam Ariyanti, 2021).

Kurangnya akses masyarakat terhadap pelayanan kesehatan, menyebabkan kurangnya kontrol terhadap keadaan penyakitnya khususnya pada lansia. Dengan adanya penyuluhan kesehatan yang diberikan kepada para pengasuh lansia, diharapkan adanya peningkatan pengetahuan yang didapatkan oleh pengasuh lansia turut membantu para lansia dalam upaya mecegah dan mengurangi gejala penyakit osteoartritis dengan melakukan latihan fisik yang telah disesuaikan dengan kondisi lansia.

Pengasuh lansia merupakan jajaran pertama dalam menjangkau lansia, ketika lansia sulit mendapatkan akses ke tenaga kesehatan. Pengasuh lansia juga dapat menjadi perpanjangan tangan dalam meningkatkan pemahaman lansia tentang status kesehatannya. Selain itu, pengasuh lansia juga merupakan jajaran terdepan dalam mentransfer pengetahuan, pemahaman, dan keterampilan dalam menangani berbagai penyakit degenratif yang terjadi pada lansia, sehingga peran pengasuh lansia di panti werdha menjadi sangat penting untuk mendapatkan pengetahuan tentang penyakit osteoarthritis itu sendiri dan berkenaan dengan peran latihan fisik dalam manajemen terpadu penyakit osteoarhtritis khususnya pada lansia.

\section{SIMPULAN DAN SARAN}

Pelatihan kesehatan kepada pengasuh lansia tentang peran latihan fisik dalam manajemen terpadu penyakit osteoarthritis pada lansia telah terlaksana dengan baik. Dari hasil evaluasi kegiatan, maka diketahui terdapat peningkatan yang signifikan pada pemahaman para pengasuh lansia terkait peran latihan fisik dalam manajemen terpadu penyakit osteoarthritis pada lansia. Dari hasil evaluasi, diketahui bahwa terjadi peningkatan pemahaman pengasuh lansia. Hal ini ditandai diketahui dengan membandingkan nilai pre test dan post test. hasil evaluasi nilai pre dan post test kegiatan PkM). Rata-Rata nilai pre test sebesar 60.00 dan Nilai Post Test sebesar 84,00 . Kegiatan ini perlu dilakukan sebagai upaya meningkatkan kesadaran, kepedulian dan mendorong keterlibatan peran pengasuh lansia dan para lansia dalam upaya manajemen terpadu pencegahan osteoarthritis melalui latihan fisik.

\section{UCAPAN TERIMAKASIH}

Tim pengabdi mengucapkan terimakasih kepada Sekolah Tinggi IImu Kesehatan Panti Waluya Malang yang telah mendanai kegiatan pengabdian masyarakat hingga selesai.

\section{DAFTAR RUJUKAN}

Aris, M. (2015). The Relations Between Obesity and Osteoarthritis Knee in Elderly Patients. J Majority, 4(5), 110-116.

Ariyanti, R., Imam, CW. (2021). Edukasi Kesehatan Terkait Upaya Swamedikasi Penyakit Osteoarhtritis Pada Lansia. SELAPARANG Jurnal Pengabdian Masyarakat Ber kemajuan; Vol 4 No 3, Agustus 2021. 
Center for Disease Control and Prevention (CDC). (2014). Osteoarthritis. Diakses pada tanggal 26 Maret 2020 dari

http://www.cdc.gov/arthritis/basics/os teoarthritis.html

Ignativicius, S., Workman. (2015). MedicalSurgical Nursing: Patient-Centered Collaborative Care (8th ed). St.Louis, Missouri: Elsevier

Kementerian Kesehatan RI. (2014). Profil Kesehatan Indonesia Tahun 2013. Diakses pada tanggal 26 Maret 2020 dari http://www.depkes.go.id

Kementerian Kesehatan RI. (2014). Riset Kesehata Dasar (Riskesdas): Penyakit Tidak Menular:Sendi Rematik Encok. Hal 94. Badan Penelitian dan Pengembangan Kesehatan. Kementerian Kesehatan RI: Jakarta

Kementerian Kesehatan RI. (2016). Menepis Serangan Osteoartritis. Diakses pada tanggal 26 Maret 2020 dari http://www.p2ptm.kemkes.go.id/doku men-p2ptm/

Kementerian Kesehatan RI. (2019). Situasi Lanjut Usia (LANSIA) di Indonesia. Jakarta: Pusat Data dan Informasi Kementerian Kesehatan RI.

Kholifah, S (2016). Keperawatan Gerontik. Jakarta: Kementerian Keseharan Republik Indonesia: Pusat Pendidikan Sumber Daya Manusia Kesehatan Badang Pengembangan dan Pemberdayaan Sumber Daya Manusia Kesehatan.

Marlina TT (2015) Efektivitas Latihan Lutut Terhadap Penurunan Intensitas Nyeri Pasien Osteoarhtritis Lutut di Yogyakarta. Jurnal Keperawatan Sriwijaya. Vol 2(1). 44-56.

Meiner, Sue E. (2011). Gerontology Nursing, Fourth Edition. United States of America: Elsevier Mosby

Nisak R, Maimunah S, Admadi T. (2018). Upay Pemberdayaan Masyarakat Melalui Deteksi Dini Pengendalian Penyakit Degeneratif pada Lansia di Dusun Karang Pucang, Desa Ngancar, Kecamatan Pitu, Wilayah Kerja Puskesmas Pitu, Kabupaten Ngawi. Ngawi: Akademi Keperawatan Pemerintah Kabupaten Ngawi

Nursalam. (2014). Metodologi Penelitian IImu Keperawatan. Jakarta: Salemba Medika

Prieharti dan Mumpuni, Y. (2017). Deteksi: Osteoartritis vs Osteoporosis Perbedaan, Seluk Beluk dan
Penanganan. Yogyakarta: Rapha Publishing

Rahmawati, R., Kusuma FHD., Widiani, E. (2012). Analisis Faktor Risiko Kejadian Osteoartritis (Sendi Lutut) pada pasien Lanjut Usia, Journal of Ners Community. Vol 3:2, 151-158.

Suari, BA., Ihsan, M., Burhanuddin L. (2015). Gambaran Penderita Osteoarhtiritis di Bagian Bedah RSUD Arifin Achmad Periode Januari 2011- Desember 2013. JOM FK. Vol 2 No.2 Oktober 2015.

Susilawati, L., Tirtayasa, K., dan Lesmana, SI. (2015). Latihan Closed Kinetic Chain Lebih baik Daripada Open Kinetic Chain untuk Meningkatkan Kemampuan Fungsional pada Osteoarthritis Lutut setelah Pemberian Micro Wave Diatherny (MWD) dan Transcutaneus Electrical Nerve Stimulation. Vol 3(10, 26-34

Tika, Pradnya dan Aryana, W. (2018). Hubungan Antara Tingkat Nyeri Berdasarkan Numerical Rating Scale dengan Intensitas Osteoartritis Secara Radiologi Menurut KallgrenLawrence Grading System Pada Penderita Osteoartritis Lutut di Rumah Sakit Sanglah. E-Journal Medika. Vol 7(6), Juni 2018. Hal 1-8

WHO. (2016). Osteoarthritis (online). Diakses pada tanggal 26 Maret 2020 dari http://www.who.int/medicines/areas/p riority_medicines/BP6_12Osteo.pdf). 